\title{
The Effects of Intellectual Capital and Financial Leverage as a Strategy to Improve Financial Performance
}

\author{
$1^{\text {st }}$ Hadiah Fitriyah \\ Faculty of Business Law and Social \\ Sciences \\ Universitas Muhammadiyah Sidoarjo \\ Indonesia \\ hadiah@umsida.ac.id
}

\author{
$2^{\text {nd }}$ Dina Dwi Octavia Rini \\ Faculty of Business Law and Social \\ Sciences \\ Universitas Muhammadiyah Sidoarjo \\ Indonesia
}

\author{
$3^{\text {rd }}$ Farida Astriana \\ Faculty of Business Law and Social \\ Sciences \\ Universitas Muhammadiyah Sidoarjo \\ Indonesia
}

\begin{abstract}
The purpose of this study was to determine the role of intellectual capital and financial leverage as a strategy to improve corporate financial performance. This study uses a quantitative approach. The object of this research is retail companies listed on the Indonesia Stock Exchange. The research sampling technique used purposive sampling. This type of data uses quantitative data and secondary data sources. Data collection techniques using documentation. Data analysis techniques using the classic assumption test and multiple regression analysis with the help of SPSS version 20 . The analysis shows that intellectual capital and financial leverage affect the financial performance of retail companies on the Indonesia Stock Exchange.
\end{abstract}

Keyword-intellectual capital, financial leverage, financial performance

\section{INTRUDUCTION}

Business people must be aware that the ability to design not only lies in tangible assets, but lies in intangible assets such as technology, innovation in managing organizations, human resources, information systems and high creativity in business are needed to improve competence competitive company (Ginesti, Caldarelli, \& Zampella, 2018). If the market is efficient, investors will place a higher value on companies with greater intellectual capital (Riahi-Belkaoui, 2003). Research result of Chen, Cheng, \& Hwang (2005) shows the company's intellectual capital has a positive impact on market value and financial performance, and can be an indicator for future financial performance. Other than that, Chen et al., (2005) find that investors can place different values on the three components of value creation (physical capital, human capital, and structural capital). Finally, evidence is presented that R\&D expenditures can capture additional information about structural capital and have a positive effect on firm value and profitability.

Some research results related to the influence of intellectual capital and company performance including conducted by Saifi (2018), Artinah (2011), and Zuliyati \& Arya (2011). The research results of Saifi (2018) show that there is a negative and significant influence of intellectual capital on the company's financial performance. Different results obtained by Artinah (2011), Zuliyati \& Arya (2011), prove that intellectual capital has a positive and significant effect on the company's financial performance. The difference in the results of Saifi (2018) research with other researchers could be because the research subjects of manufacturing companies that are used have different characteristics from the banking or financial sector that are widely studied by other researchers. In addition, financial performance measurement tools used by researchers, Return on Assets (ROA) and Return on Equity (ROE), require different financial data that might affect the final results of the study. Meanwhile, Artinah (2011) added the three components of intellectual capital in her research to partially test the effect of each of these components on the company's financial performance. The results of his study indicate that employed capital efficiency (physical capital) has a positive and significant effect. These positive and significant influences are supported by research conducted by Zuliyati \& Arya (2011). Bontis \& Keow (2000) explained that there are four experts who have the same opinion that assets in a company are human resources and therefore the importance of human resources. Brooking believes that a manager's skills and leadership style possessed by a leader are important components in human capital. Brooking also shows that structural capital is divided into two components, namely infrastructure assets and intellectual property. Included in infrastructure assets are technology and all processes that enable companies to function. Whereas Roos added the importance of culture. However, Bontis \& Keow (2000) say that intellectual property is not included in the intellectual capital 
component because the intellectual property audit is not a new idea and intellectual property is a protected asset and has a legal definition (unlike other intellectual capital components).

This study aims to examine the effect of intellectual capital and financial leverage on the financial performance of companies in retail companies listed on the Stock Exchange. Retail companies must survive and be able to innovate in the face of increasingly fierce market competition to improve company performance. According to Ma'ruf (2005) a retail company is a business activity of selling goods or services to individuals for their own, family or household needs. Ma'ruf (2005) adds that they sell goods (or services) directly to consumers. The retail business is the sale of products and services to end customers, but it is not uncommon to find consumers in retail businesses reselling products purchased for profit. Therefore, retail companies must be able to increase the assets owned by the company, both tangible assets and intangible assets to be able to survive and be sustainable now and in the future.

\section{THEORETICAL STUDIES}

The intellectual capital component consists of 3 categories Bontis \& Keow (2000) Human Capital (HC), human capital can be defined based on a set of abilities, traits and attitudes of the employees of a company. Human capital is the key to innovation and improvement, because in it there is knowledge, skills and competencies possessed by company employees. Human capital can increase if the company can utilize and develop the knowledge, competencies and skills of its employees efficiently. Therefore, human capital is a key resource that can create a competitive advantage so that the company is able to compete and survive in a dynamic business environment. By having skilled and skilled employees, it can improve company performance and ensure the sustainability of the company. Increased company performance will also improve market perception; 2) Structural Capital (SC), structural capital consists of corporate culture, innovation and business processes. Structural capital is the ability of an organization to meet the company's routine processes and structures that support the efforts of employees to produce optimal intellectual performance and overall business performance; 3) Relational capital (RC), relational capital is a component in establishing a good relationship between the company and all stakeholders. Relational capital can arise from various parts outside the company environment that can add value to the company. Cabrita, Rosario, Bontis, \& Nick (2008) revealed that intellectual capital can be interpreted as an intangible asset that can be utilized to increase the value and competitiveness of a company.

Human capital will increase if salaries, bonuses and benefits provided by the company to employees are in accordance with what they do. So employees can create added value and increase company revenue and profits. value added is used as a measurement tool created by stakeholders in analyzing Human capital (Ulum, 2012). This can be interpreted that the company is able to maximize Knowlage, Skill, and Network so as to create value, so that shareholders can benefit from shareholders. So it can be concluded that human capital has a positive relationship and a significant influence on profitability. Structural capital (SC) is used by companies to assess optimal company performance results, as well as overall business performance, for example the company's operational systems, manufacturing processes, organizational culture, management philosophy and all forms of intellectual property owned by the company (Sawarjuwono \& Kadir, 2003). Therefore, to get a good structural capital (SC), it will increase employee productivity in generating added value and can help improve company performance. So it was concluded that structural capital has a positive relationship and has a significant influence on profitability. Sawarjuwono and Kadir (2003) say that intellectual capital itself is still not widely known in Indonesia. This is because companies in Indonesia still use conventional based in building their business, and these companies have not paid more attention to human capital, structural capital, or customer capital. If these companies follow existing developments, namely knowledge-based management, companies in Indonesia can compete competitively through creative innovations generated by the company's intellectual capital.

Based on research (Saputra, 2018), which obtained the results that intellectual capital affects the company's financial performance. If intellectual capital in a company can be run effectively and efficiently, then knowledgebased resources can be realized by the company. In addition, the company can also manage and utilize its strategic resources effectively so that it will realize a competitive advantage in the company which will ultimately improve company performance.

In contrast to the results of research conducted by Supriatna, Triantoro, \& Rustandi (2013) explains that the research that has been done shows that intellectual capital has a positive effect on profitability, intellectual capital has a negative effect on productivity, and capital has no effect on market valuation. research (Ningrum, 2014) shows that intellectual capital and financial levarage have a significant positive effect on company profitability. In line with the research conducted by Paul (2017) in his research explained that the researcher observed that Return on Equity is significant for the return of assets, net profit margins, and asset turnover. It is also observed that the Return on Assets is significant for the return of Equity, Net Profit Margin, and Asset Turnover. Net Profit Margins are also significant for Equity Returns, Asset Returns and Asset Turnover. Asset turnover is also important for Return on Equity, Return to Assets and Net Profit Margin. In addition to value-added resources, economic resources including corporate funding are also the most important things in maximizing company profitability. A good funding policy can increase company value if company management is able to use the company's economic 
resources effectively and efficiently. One alternative funding policy that is quite important is financial leverage (Jannati, Saifi, \& Endang, 2014). Financial leverage can be used to meet the funding needs of the company so that the company can operate, invest, and develop its business. Financial leverage is expected to provide additional greater benefits for shareholders. This is based on the amount of fixed interest expense from debt which can reduce the amount of tax. However, financial leverage can also adversely affect the company because high financial leverage will cause the company's financial difficulties to be able to settle its debt obligations (Jannati et al., 2014). Leverage is usually used in describing the ability of companies to use assets or funds that have a fixed cost (fixed cost assets or funds) to increase the level of income (return) for company owners (Jannati et al., 2014).

Hypothesis

$\mathrm{H} 1$ : Intellectual capital affects the financial performance of companies in retail companies listed on the Indonesia Stock Exchange

$\mathrm{H} 2$ : Financial leverage affects the financial performance of companies in retail companies listed on the Indonesia Stock Exchange

\section{METHOD}

The research approach used in this study is a quantitative approach, to provide a picture that explains a phenomenon that has been studied (Cooper \& Schindler, 2006). The data source uses secondary data taken from the Indonesia Stock Exchange (IDX) annual report which can be accessed on the site www.idx.co.id. The sample technique in this study uses a purposive sampling technique where the sample is determined based on criteria chosen by researchers Sugiyono (2017) on the financial statements of retail companies listing on the Indonesia Stock Exchange in 2015-2017. The sample criteria used are: 1) listed as a retail company listing on the Indonesia Stock Exchange in 2015-2017 and never delisting during that period; 2) the company periodically reports its financial statements annually and has complete data during the observation period. The analysis technique used in the data processing process is using linear regression analysis with the help of SPSS version 20 . The steps that must be carried out in using multiple linear analysis techniques are: 1) classic assumption test, including: normality test, autocorrelation test, test heterogeneity, multicollinearity test and 2) hypothesis test.

\section{RESEARCH RESULTS AND DISCUSSION}

A. Research result

Results of multiple linear regression analysis:

TABLE I. RESULTS OF MULTIPLE LINEAR REGRESSION ANALYSIS COEFFICIENTS ${ }^{\mathrm{A}}$

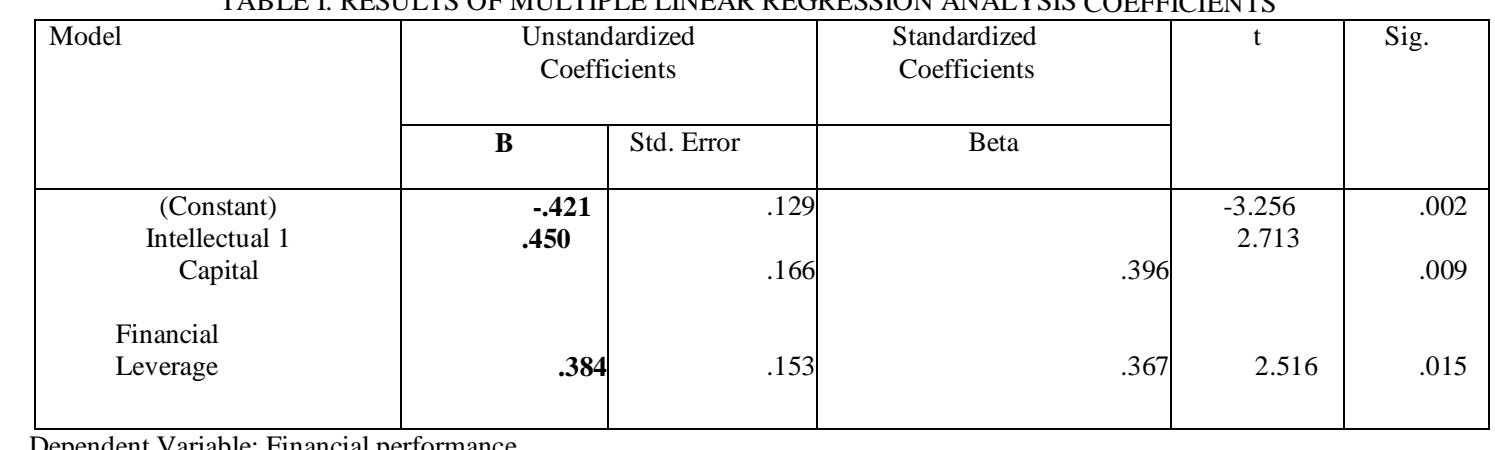

a. Dependent Variable: Financial performance

In the analysis of multiple linear regression there are equations that describe the effect of two or more independent variables. The following results of multiple linear regression analysis in this study:

$\mathrm{Y}=-0,421+0,450 \mathrm{X} 1+0,384 \mathrm{X} 2+\mathrm{e}$.

The equation has the following meanings: 1) a constant value of -0.421 . This means that without the influence of intellectual capital and leverage the variable value of financial performance remains at -0.421 ; 2) intellectual capital variable coefficient value of 0.450 . It means that every increase of one unit of intellectual capital variable will cause an increase in the variable of financial performance by 0.450 assuming the other factors are constant; 3) the coefficient value of the financial leverage variable is 0.384 .

This means that every increase of one unit of financial leverage variable, will result in a variable financial performance of 0.384 assuming the other factors are constant. Table 1 also shows that: 1) the variable intellectual capital has a tcount of 2.713> ttable of 2.00665 with a significance level of $0.009<0.05$. This means that partially intellectual capital variables significantly influence financial performance variables; 2) financial leverage variable has a tcount of 2.516> ttable of 2.00665 with a significance level of $0.015<0.05$. This means that partially financial lever variable has a significant influence on financial performance variables.

B. Discussion

The results showed that:

- Intellectual capital affects the financial performance of retail companies listed on the Indonesia Stock Exchange in 2015-2017. In this research, intellectual capital is defined as a knowledge resource consisting of employees, customers, processes or technology which the company can use in the process of creating value for the company. Intellectual capital as an intangible asset with the ability to provide value to companies and the public 
includes patents, intellectual property rights, copyrights, and franchises. From the results of data analysis, the results show that intellectual capital has a significant effect on financial performance of retail companies on the Indonesia Stock Exchange in the 2015-2019 period. This means that the higher the company's intellectual capital will be able to improve the company's financial performance. This condition occurs because intellectual capital is increasing, so the company has used its capital more effectively to improve the ability of human resources, so that employee performance to generate profits is increasing.

Intellectual capital that is managed well by the company, will reflect the company's good financial performance. This will make more and more investors invest their funds, so that it will have an impact on the rate of return that is more for the company's management. Intellectual capital as intellectual property is centered on human resources that has the function of increasing the competitiveness of human resources of the company. The better the ability of human resources, it will produce good performance for the company, so that the company's profits will also increase.

In line with research conducted by Saputra, et al , Chen, et al (2005) and Firer and William (2003) who obtained the results that intellectual capital influences the company's financial performance. If intellectual capital in a company can be run effectively and efficiently, then knowledge-based resources can be realized by the company. In addition, the company can also manage and utilize its strategic resources effectively so that it will realize a competitive advantage in the company which will ultimately improve company performance. This research is also supported by the results of previous studies conducted by ((Nimtrakoon, 2015);(Soetanto \& Liem, 2019); (Sardo \& Serrasqueiro, 2017); (Ginesti et al., 2018); (Vishnu \& Gupta, 2014)).

- Financial leverage affects the financial performance of companies in retail companies listed on the Indonesia Stock Exchange in 20152017. In this study, financial leverage is interpreted as a level of uncertainty (uncertainty) of the return that will be obtained will be higher as well, but at the same time it will also increase the amount of return to be obtained. This level of leverage can vary from one company to another, which is clearly the higher the level of leverage the higher the risk faced and the greater the level of expected return or income.

The analysis shows that financial leverage has a significant effect on financial performance of retail companies on the Indonesia Stock Exchange in the 2015-2017 period. This means that the more leverage the company has, the higher the company's financial performance, even though the risk faced is also higher. This can be caused by high leverage as the company's capital in carrying out its operational activities. Although it has a high risk, if managed properly it will get the maximum profit. Supported by the opinion of Jannati, et al (2014), where leverage illustrates the ability of companies to use assets or funds that have a fixed cost (fixed cost assets or funds) to increase the level of income (return) for company owners. In line with research (Ikhsani, Fadilah, \& Sukarmanto, 2016), which obtained the results of partial leverage has a significant effect on the company's financial performance. The higher the value of leverage, shows the amount of loan capital used by companies to invest in assets is greater. This will be able to increase the company's ability to obtain profits or profits, because the operational funds owned are relatively more. In general, companies use leverage to meet the lack of funds in the company. The results of Paul's (2017) and Rehman (2013) research show that there is a significant relationship between financial leverage and asset returns.

\section{CONCLUSION}

The analysis shows that intellectual capital and financial leverage affect the financial performance of retail companies on the Indonesia Stock Exchange in the 2015-2017 period. This shows that companies that have the resources and knowledge and are able to manage it well, the company will have a competitive advantage that will have an impact on high financial performance. Good management, will increase sales of company goods and services, and also reduce costs so that profitability will increase.

\section{REFERENCES}

[1] Bontis, N, W. C. C., \& Keow, S. R. (2000). "Intellectual Capital And Business Performance In Malaysian Industries". Journal of Intellectual Capital. Vol. 1 No. 1. pp. 85-100.

[2] Cabrita, Rosario, M. do, Bontis, \& Nick. (2008). Intellectual Capital and Business Performance in the Portuguese Banking Industry. Int. J. Technology Management. Vol. 43. Nos. 1-3.

[3] Chen, M.-C., Cheng, S.-J., \& Hwang, Y. (2005). An empirical investigation of the relationship between intellectual capital and firms' market value and financial performance. Journal of Intellectual Capital, 6(2), 159-176. https://doi.org/10.1108/14691930510592771.

[4] Cooper, D. R., \& Schindler, P. S. (2006). Business Research Methods(9thedition)(McGraw-Hill). Firer, S. and Williams, M. (2003). Intellectual capital and traditional measures of corporate performance, Journal of Intellectual Capital, Vol. 4 No. 3, pp. 348-60.

[5] Ginesti, G., Caldarelli, A., \& Zampella, A. (2018). Exploring the impact of intellectual capital on company reputation and performance. Journal of Intellectual Capital, 19(5), 915-934. ttps://doi.org/10.1108/JIC-01-2018-0012.

[6] Ikhsani, A. N., Fadilah, S., \& Sukarmanto, E. (2016). Pengaruh Intellectual Capital, Modal Kerja, dan Financial Leverage terhadap Profitabilitas Perusahaan, 2(2), 417-425.

[7] Jannati, I. D., Saifi, M., \& Endang. (2014). Pengaruh rasio leverage terhadap profitabilitas (Studi pada perusahaan makanan dan minuman yang terdaftar di BEI periode tahun 2009-2011). Jurnal Administrasi Bisnis, 8(2), 1-8.

[8] Nimtrakoon, S. (2015). The relationship between intellectual capital, firms' market value and financial performance: Empirical evidence from the ASEAN. Journal of Intellectual Capital, 16(3), 587-618. https://doi.org/10.1108/JIC-09-20140104.

[9] Ningrum, kiki E. M. (2014). Efek Intellectual Capital dan Leverage Keuangan terhadap Profitabilitas Perusahaan 
Perbankan yang Terdaftar di Bursa Efek Indonesia (The Effect of Intellectual Capital and Financial Leverage on Profitability of Bank Firm Listed in Indonesia Stock Exchang).

[10] Paul, O. U. (2017). The Impact of Leverage Financing on Financial Performance of Some Manufacturing Industries in Nigerian Stock Exchange. Saudi Journal of Business and

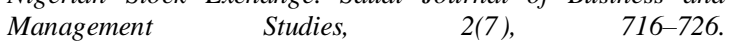
https://doi.org/10.21276/sjbms.

[11] Rehman, S. .(2013). Relationship between financial leverage and financial performance: Empirical Evidence of listed sugar companies of Pakistan. Global Journal of management and Business Research finance 13(8): 33 -40.

[12] Riahi-Belkaoui, A. (2003). Intellectual capital and firm performance of US multinational firms: a study of the resourcebased and stakeholder views", Journal of Intellectual Capital, Vol. 4 No. 2, pp. 215-26.

[13] Saifi, M. (2018). ANALISIS INTERNET FINANCIAL REPORTING ( IFR ) ( Studi Pada Perusahaan Manufaktur Yang Go Public di Indonesia, Singapura, dan. 56(1), 100-109.

[14] Saputra, D. (2018). Pengaruh Intellectual Capital Terhadap Kinerja Keuangan Pertumbuhan Perusahaan dan Nilai Pasar pada Perusahaan Property dan Real Estate yang terdaftar di Bursa Efek Indonesia. Jurnal Manajemen dan Bisnis, Vol. X No. 2 hal. 385-407.

[15] Sardo, F., \& Serrasqueiro, Z. (2017). A European empirical study of the relationship between firms'intellectual capital, financial performance and market value. Journal of Intellectual Capital, 18(4), 771-788. https://doi.org/10.1108/JIC-10-20160105.

[16] Sawarjuwono, T., \& Kadir, A. P. (2003). Intellectual capital: Perlakuan, pengukuran dan pelaporan (sebuah library research). Jurnal Akuntansi \& Keuangan, 5(1), 35-37.

[17] Soetanto, T., \& Liem, P. F. (2019). Intellectual capital in Indonesia: dynamic panel approach. Journal of Asia Business Studies, 13(2), 240-262. https://doi.org/10.1108/JABS-02-20180059.

[18] Sugiyono. (2017). Metode Penelitian Bisnis. Bandung: Cv Alfabeta.

[19] Supriatna, N., Triantoro, A., \& Rustandi, R. (2013). Pengaruh Intellectual Capital Terhadap Kinerja Keuangan Pada Perusahaan Retail Yang Terdaftar Di Bursa Efek Indonesia (Bei) Pada Tahun 2009-2011. Jurnal Riset Akuntansi Dan Keuangan Program Studi Akuntansi Fakultas Pendidikan Ekonomi Dan Bisnis Universi.

[20] Ulum, I. (2012). Konstruksi Komponen Intellectual Capital untuk Perguruan Tinggi di Indonesia. Jurnal Reviu Akuntansi Dan Keuangan, 2(2), 251-262. https://doi.org/10.1016/S01679473(97)//00038-8. Vishnu, S., \& Gupta, V. K. (2014). Intellectual capital and performance of pharmaceutical firms in India.

[21] Journal of Intellectual Capital, 15(1), 83-99. https://doi.org/10.1108/JIC-04-2013-0049.

[22] Zuliyati, \& Arya, N. (2011). Intellectual Capital dan Kinerja Keuangan Perusahaan (Intellectual Capital and Company's Financial Performance). Dinamika Keuangan dan Perbankan. Vol. 3. No. 1.S. 